\title{
One Hundred Years of Evidence Law Reform: Thayer's Triumph
}

\author{
Eleanor Swift $\dagger$
}

TABLE of CONTENTS

Introduction.

I. A Preliminary Discussion of the Meaning of "Judicial

Discretion" to Admit or Exclude Evidence.

A. Defining Discretion in the Decision to Admit or

Exclude Evidence

B. Categorical Decisions: The Different Approach of

Bright-Line Rules

C. The Benefits and Costs of Discretion

II. The Beginning of Reform: Thayer's Definition of the "Law of Evidence".

A. Narrowing the Range of Cases that Constitute the "Law of Evidence"

B. Understanding Evidence Law as the Child of the

Jury System

C. Focusing on the General Principles of Exclusion

III. Thayer's View of Judicial Discretion: The Cure for the

General Ills of Evidence Law

IV. The Model Code of Evidence: Morgan v. Wiginore.

A. Two Different Approaches to Reform.......................................2455

B. A Catalogue, a Creed, or a Code?

C. Judicial Discretion as Adopted by the Code

.2459

V. Thayer's Modern Incarnation: Judicial Discretion in the

Federal Rules of Evidence

A. The Use of Discretion Erodes Categorical Constraints in the Admission of Hearsay

Copyright (C) 2000 California Law Review, Inc. California Law Review, Incorporated (CLR) is a California nonprofit corporation. CLR and the authors are solely responsible for the content of their publications.

$\dagger \quad$ Professor of Law, School of Law, University of California, Berkeley (Boalt Hall). My thanks to my research assistants Melissa Clayton and John Tydlaska. They kept me laughing. 
B. Supreme Court Interpretations of Rule 702 Enlarge

Trial Court Discretion................................................................22466

C. Trial Court Discretion Broadened to Admit Character Evidence to Prove Conduct ...................................................2468

VI. Thayer's Triumph? New Ills from an Excess of Trial Court

Discretion

Conclusion 


\title{
One Hundred Years of Evidence Law Reform: Thayer's Triumph
}

\author{
Eleanor Swift
}

This Essay traces the history of twentieth century evidence reform through the codification efforts led by three great evidence scholars: Thayer, Wigmore and Morgan. This codification movement resulted in the drafting of the Federal Rules of Evidence in 1975, and their subsequent adoption by over forty states. In particular, Swift focuses on the writings of Thayer and brings his achievements in the field to the attention of the current generation of evidence students.

Thayer, and many other major twentieth century reformers, advocated increasing the discretion of the trial judge to admit or exclude evidence. Swifi defines what is meant by "discretion" in this context, and contrasts the operational thinking required of judges under a standard of discretion with the categorical thinking required by bright-line rules. The debate over discretion is then sketched through Wigmore's and Morgan's competing approaches to codification, the failure of the Model Code of Evidence in the 1940s, and the ultimate success of the Federal Rules.

Now that Thayer's call for increased discretion has triumphed, however, troublesome issues of an "excess" of trial court discretion are raised in three areas of law: hearsay, expert opinions and character. Swift describes how recent developments permit trial judges to ignore bright-line rules and, in the area of expert opinion, to make essentially unreviewable determinations regarding the admission or exclusion of outcomedeterminative scientific evidence. She identifies fundamental values that are threatened by these developments and posits that the changing nature and context of litigation at the end of the twentieth century make excess discretion even more problematic.

\section{INTRODUCTION}

This Essay traces the development of the debate over trial court discretion that has shaped the past one hundred years of evidence law reform. The history of this debate is dominated by three towering figures in the field of evidence law: James Bradley Thayer, John Henry Wigmore, and Edmund M. Morgan. The writings of these scholars are becoming less well known to students of evidence, and the contribution they made to the reform movement that culminated in the Federal Rules of Evidence is 
perhaps not keenly appreciated. The purpose of this centennial symposium Essay, therefore, is to memorialize these early twentieth-century evidence law reformers, to comment briefly on the trial court discretion debate that continues today, and to caution against the seemingly inexorable trend toward the expansion of that discretion.

This history of twentieth-century efforts to reform the law of evidence begins with the writings of Professor Thayer, certainly one of the greatest of all evidence scholars.' Thayer's contributions were twofold. First, he narrowed the field of evidence law to the study of rules pertaining only to the trial court's decision to admit or exclude evidence. Second, he proposed that the law of evidence be changed so that courts of appeal would no longer craft specific, detailed doctrinal rules that controlled the lower courts. Thayer advocated instead a regime of broad principles designed to ensure both substantial flexibility in trial court decision making and considerable immunity from appellate court review.

Thayer's call for "an extension of judicial discretion and a radical simplification of the law of evidence"2 remained the principal topic of evidence law reform for the rest of the century. Professor Wigmore, known as the leading compiler of and authority on the law of evidence for the entire first half of the twentieth century, ${ }^{3}$ favored the expansion of judicial discretion, which to him meant freeing the trial court's evidentiary decisions from appellate review. Wigmore differed from Thayer, however, in believing that detailed guidelines, not broad principles, should guide the decision making of trial judges. Thus he rejected the efforts of another great evidence law reformer, Professor Morgan, who served as the Reporter of the 1930 draft of the Model Code of Evidence. ${ }^{4}$ This Code, a thoroughgoing attempt to simplify the law of evidence and to expand the authority of the trial judge over the trial process, was not adopted in a single jurisdiction. Wigmore's rejection of the Code played a role in its lack of success, as did its substantial enlargement of trial court discretion. Although the Code's proposed reforms to the law of evidence were never put into practice, it played a significant role in the continuing debates over trial court discretion and codification.

Successive efforts to codify the law of evidence culminated in the Federal Rules of Evidence, adopted by Act of Congress in 1974. The

1. See, e.g., William Twining, Theories of Evidence: Bentham and Wigmore 5-6 (1985) (Thayer "exerted tremendous influence through his teaching, his casebooks on evidence ... and his superb volume of historical and analytical essays ....").

2. Id. at 7 .

3. Wigmore produced what Thayer was unable to accomplish in his lifetimc-a complete treatise on evidence law. This multivolume treatise, so popular that it was published in thrce cditions between 1904 and 1940, is still in use today in editions revised by leading evidence academics. See infra notes 66-73 and accompanying text.

4. MODEL CODE OF EVIDENCE (1942) [hereinafter MODEL CODE]. 
Advisory Committee that drafted these Rules sought uniformity rather than reform, abandoning some of the radical pro-admission changes of the Model Code. In this the drafters succeeded. The Federal Rules have dominated the field of evidence during the last quarter of the twentieth century, having been adopted (with some modifications) in approximately forty states. The drafters tempered somewhat the Code's emphasis on judicial discretion by adhering to more traditional substantive principles while still injecting discretionary language into the text of some Rules. More recently, a powerful trend toward expanding such discretion has been fueled by amendments to the Rules, by the United States Supreme Court's interpretations of the Rules, and by the gradual erosion of existing doctrinal limits through trial court decision. At the end of the twentieth century, then, it seems that Thayer's call for the extension of judicial discretion has triumphed. This Essay concludes, however, that this triumph may pose a serious challenge to our system of adjudication, and to the values of fairness, equality, and individual autonomy that underlie it. This challenge is readily observed in cases dealing with hearsay, expert testimony, and the use of character evidence to prove conduct.

I

\section{A Preliminary Discussion of the Meaning of "Judicial Discretion" TO ADMIT OR EXCLUDE EVIDENCE}

To Thayer, Wigmore, and Morgan, extending the judge's "discretion" to admit or exclude evidence meant freeing this decision from the burden of the common law system of appellate court precedent that purported to control, through detailed rules of law and findings of trial court error, the outcomes in a large number of cases. ${ }^{5}$ Central to the project of all three reformers was narrowing the scope of, or prohibiting altogether, appellate review of the trial judge's decision to admit or exclude evidence. ${ }^{6}$ Without the old precedent, and without the fear of review and reversal, trial courts

5. Thayer described the trouble with appellate review and appellate elaboration of evidence rules as follows:

[T] exceptions that are refined upon, discriminated, and run down into a nice and difficult attenuation of detail, so that the courts become lost ... or perhaps are at a loss to say whether the controlling principle is to be found in the exception or in the general rule ....

James Bradley Thayer, A Preliminary Treatise on Evidence at the Common Law 512 (1898) [hereinafter Thayer, Preliminary Treatise].

6. In the passage that most directly states his view of discretion, Thayer wrote:

Now in the application of such standards as these [considerations of confusing, misleading, or tiring the minds of the jury], the chief appeal is made to sound judgment; to what our lawyers have called, for six or seven centuries at least, the discretion of the judge. Decisions on such subjects are not readily open to revision; and, when revised, they have to be judged of in a large way; this is expressed by saying that the question is whether the discretion has becn unreasonably exercised, has been abused.

Id. at 516 . 
would have greater freedom to exercise their own judgment about admitting evidence, and could thus be maximally responsive to the particular facts and courtroom developments of the specific case.

Thayer and Morgan, but not Wigmore, also advocated that evidence law should consist of principles rather than detailed rules in order to promote the exercise of trial court discretion. ${ }^{7}$ In this context, the word "discretion" has a particular meaning. It should not be confused with other uses of the word, such as the ability of judges to engage in "interstitial judicial 'legislation,' ... the making of choices between possible conduct-controlling standards." Nor is it decision making that is free from restraint, that "will not be controlled by authoritative standards ...." As advocated by Thayer and Morgan, and as understood in evidence law today, the exercise of discretion to admit or exclude evidence is defined by specific and salient characteristics.

\section{A. Defining Discretion in the Decision to Admit or Exclude Evidence}

First, the exercise of judicial discretion in admitting or excluding evidence is, to use Professor Jon R. Waltz's term, "guided" decision making. ${ }^{10}$ The judge's choice to admit or exclude is not unrestrained by fixed principles. Rather, the judge has some flexibility in choice of outcome, but is restrained by standards articulated in the rules of evidence law. These

7. Morgan favored the complete Thayerian view of discretion, which he embodied in the Model Code of Evidence. He wrote in his Foreword:

The gencral language in which the Rules are drawn gives wide seope for the exercise by [the judge] of an honest judgment in the circumstances of the particular case.... [T] here runs through the whole Code the theory that the trial judge dircets and controls the conduet of the trial, and that [the judge's] action is final except where an abuse of ... discretion results in material prejudice to the substantial rights of the losing litigant. MODEL CoDE, supra note 4, at 14-15.

Wigmore embraced only part of this vision of discretion. He advocated more speeific rules rather than general principles because he thought they would be clear, easy to apply without discussion, and would provide predictability to lawyers preparing for trial. Dccisions under these rules, however, were to be completely insulated from appellate review, thus preserving trial court freedom from the strictures of preccdent.

8. Jon R.Waltz, Judicial Discretion in the Admission of Evidence Under the Federal Rules of Evidence, 79 Nw. U. L. REv. 1097, 1100 (1985). A large literature on trial court diseretion in evidentiary decision making has developed since the days of Thayer, Morgan, and Wigmore. See, e.g., Kenneth Culp Davis, Discretionary Justice: A Preliminary Inquiry (1969); Victor J. Gold, Limiting Judicial Discretion to Exclude Prejudicial Evidence, 18 U.C. DAvIS L. REV. 59 (1984); David P. Leonard, Power and Responsibility in Evidence Law, 63 S. CAL. L. REv. 937 (1990); Thomas M. Mengler, The Theory of Discretion in the Federal Rules of Evidence, 74 IowA L. REv. 413 (1989). Other helpful articles about trial court discretion include George C. Christie, An Essay on Discretion, 1986 DuKE L.J. 747 (1986) and Maurice Rosenberg, Judicial Discretion of the Trial Court, Viewed from Above, 22 SYRACUSE L. REV. 635 (1971).

9. Leonard, supra note 8, at 943. Professor Leonard relies on the work of Professor Ronald J. Dworkin in identifying tbis "strong" version of discretion. Id. at 942-43.

10. Waltz, supra note 8 , at 1103. 
standards may come from a code or from appellate rulings, and the judge must apply them on the record.

The primary example of guided discretion in modern evidence law is Federal Rule of Evidence 403, which states a rule of exclusion that applies to most trial court decisions:

Although relevant, evidence may be excluded if its probative value is substantially outweighed by the danger of unfair prejudice, confusion of the issues, or misleading the jury, or by considerations of undue delay, waste of time, or needless presentation of cumulative evidence. ${ }^{11}$

The criteria that the judge must consider in deciding whether to admit or exclude the evidence-probative value, danger of unfair prejudice, and so on-are explicitly stated, although not defined. The standard by which the judge must compare them in order to exclude an item of evidence-the danger must substantially outweigh the value-is also established. The trial judge must consider only these criteria, and must adhere to the Rule's overtly pro-admission standard unless a categorical rule requires admission or exclusion.

Second, discretion also connotes a functional mental process, requiring the judge to apply non-mechanical criteria and standards that call for the use of judgment. ${ }^{12}$ Evaluating an offered item's "probative value" under Rule 403, for exaniple, necessitates judgments that estimate both the probability of inferences that link that item to the disputed proposition to be proved, and the probative impact of the item in the context of the case. The judge must also evaluate the quality of the danger, such as "unfair prejudice," that an item may present to jury decision making, and estimate the likelihood and degree of that danger, again in the context of the specific case. The comparison of probative value to such dangers also requires judgment, taking the form of "interest balancing" or "factor analysis," which, according to Professor George Christie, has become the dominant technique for making judicial decisions "more sensible accommodations of the often conflicting imperatives of public policy." 13

The third salient characteristic of discretion, well understood by Thayer, Wigmore, and Morgan, is that it is subject to a deferential standard of appellate review. Commentators have described discretion as a

11. FED. R. Evid. 403.

12. See Ronald M. Dworkin, The Model of Rules, 35 U. CHr. L. Rev. 14, 32 (1967). Professor

Victor J. Gold describes this judgment process as follows:

First the judge's experience concerning the usual juror reaction to the type of evidence in question is relevant. Second, the judge must be sensitive to how jurors in the instant case are likely to respond, given their particular backgrounds. Finally, the specific context in which the evidence is offered must be considered.

Gold, supra note 8, at 69.

13. Christie, supra note 8 , at 765 . 
"review-restraining concept."14 Thus, it insures a tolerance for a range of trial court decisions that the appellate judges would not have made themselves. If appellate judges applied a nondeferential, de novo standard of review to Rule 403 decisions-reversing the trial court simply because they disagreed with its outcome-they would have to justify their own decision in one of two ways: either by reapplying to the specific facts of the case the factors that guided the judgment of the trial judge (in the case of Rule 403, the estimation, evaluation, and comparison process described above), or by announcing a more rigid, result-oriented doctrinal test that would, theoretically, have to be applied by trial courts whenever similar facts appeared. ${ }^{15}$

Either method of applying a nondeferential standard of appellate review would produce undesirable results. De novo reexamination of the trial court's multifactored judgments to admit or exclude evidence under Rule 403 would lead to vast expenditure of judicial resources, more findings of error, and a lack of finality throughout the judicial system. Equally important, trial judges probably make better decisions on such questions than do appellate courts. Trial judges are closer to the immediate facts of the case on which the necessary estimations and evaluations must be based, and there is no way that appellate courts can take into account much of the context of the case. The trial court also has better practical experience in making such decisions. Moreover, given the fact-specificity of the exercise of judgment required, such decisions have little precedential value. ${ }^{16}$ Professor David P. Leonard contends that appellate courts may not even be in a position to determine whether the trial court got it right or wrong, given the complexity of applying judgment-based rules to the facts of a case. ${ }^{17}$ Only rarely are there clearly right or wrong estimations or evaluations that control an outcome. Appellate court imposition of result-oriented doctrinal tests, the second type of nondeferential review, would therefore be highly artificial, and would lead to exactly the kind of rigidity, loss of

14. Leonard, supra note 8 , at 942 . This characteristie of trial court discretion is discussed by Professor Rosenberg, supra note 8, at 638.

15. As an example, appellate courts have frequently considered decisions of trial judges admitting or excluding evidence of the defendant's driving speed some distance before the place where the crash (for which the defendant is charged with liability due to speeding) occurred. Rather than simply deferring to the trial court's estimation of probative value versus risk of prejudicing or misleading the jury, the appellate court might announce a bright-line rule stating that, at certain distances, a defendant's rate of speed was inadmissible. See, e.g., Euson v. Starrett, 277 F.2d 73, 77 (1960) (finding distances of one and one-half and three-quarters of a mile "too remote" from thc accident without additional evidence).

16. These are factors that justify relatively open-ended discretion in the trial court and deference from the appellate court, even when the two tribunals disagree. See generally Christie, supra note 8, at 772-78 (formulating this argument with regard to judicial deference to fact finding by the jury).

17. See Leonard, supra note 8, at 1004-05. 
context, and loss of creativity in the conduct of trials that Thayer, Wigmore, and Morgan criticized. ${ }^{18}$

Deferential appellate review of discretion, as advocated by Thayer, Wigmore, and Morgan, is more limited. Reversal is justified not when the appellate court disagrees with an outcome, but only when the trial court "abuses" its discretion. Such abuse can occur if the court did not apply the requisite guidelines to its decision making, did not give these guidelines their received meaming, or reached a result plainly against the logic and effect of the facts of the case. ${ }^{19}$ Under this standard, a range of trial court outcomes on similar facts would be upheld, but appellate courts could use their power of reversal to clarify guidelines, eliminate factors that trial courts must not consider, and require that decision making take place on the record to increase accountability. ${ }^{20}$ Detailed, outcome-determinative doctrinal tests would not be applied.

\section{B. Categorical Decisions: The Different Approach of Bright-Line Rules}

It is important to distinguish rules that require and guide the exercise of discretion from another type of evidence rule, the so-called bright-line rules that control admission and exclusion decisions with doctrinal categories rather than with estimates of probative value. These categorical rules operate to cabin trial court discretion in two ways: some establish categories that require judicial fact finding ${ }^{21}$ while others establish categories that require the trial judge to identify specific theories of relevance. ${ }^{22}$ Under both types of categorical rules, the trial judge's task is to determine whether the proffered item of evidence fits within a doctrinal category. This decision of whether the item "fits" then determines admission or exclusion. Thus, discretion as that term has just been described here is not exercised. This is not because the categorical terms are applied

18. "If one seeks objectivity in judicial decision making, one may have no choice but to accept a certain simplification, even artificiality." Christie, supra note 8, at 778 (again, comparing jury determinations to formal judicial decision making).

19. See Waltz, supra note 8 , at 1104 . Waltz also states that "[a]buse' is a misnomer, carrying with it an implication of judicial perversity that is almost never justified or intended." Id. at 1103-04. It is true that, under this definition, the appellate court has the power to substitute its judgment, on the specific facts, for that of the trial judge. "All one can say is that appellate courts will sometimes use the power they have over trial courts to second-guess them. When they will and when they will not very often seems rather subjective." Christie, supra note 8, at 757. Nevertheless, the deferential abuse of discretion standard of review greatly reduces the number of these second-guessing decisions and confines them to those cases where the trial judge seems to have misconstrued the meaning of the discretionary terms being applied.

20. Appellate court imposition of these internal and external constraints is advocated by Professor Leonard as part of the "heavy degree of responsibility that comes with an evidentiary system pervaded by judgment-based rather than fixed rules." Leonard, supra note 8 , at 988 .

21. The best examples of these are the definition of "hearsay" under Rule 801(a) and the hearsay exemptions and exceptions of Rules 801(d), 803, and 804. See FED. R. Evid. 801, 803, 804.

22. The best example of this is the permissible uses of specific acts under Rule 404(b). 
mechanically. They still require a very careful, but different, kind of thinking by the trial judge. Most important, there is no explicitly acknowledged estimation of probative value involved in the admission decision; rather, the doctrinal categories establish bright-line cut-offs based on generalized, legislative judgments of probative worth. Thus, for example, trial judges do not estimate the probative value of a hearsay statement in order to admit it; they engage in fact finding to classify it under the bright-line categorical exceptions. Nor is there any need to take into account the larger context of the case under a categorical rule. Both probative value and risk of the Rule 403 dangers are taken into account in the drafting of the categorical

requirements themselves. The difference between categorical and discretionary thinking will be further demonstrated in Part V of this Essay, in which the recent trend toward erosion of bright-line rules through the application of Rule 403 balancing is discussed.

\section{The Benefits and Costs of Discretion}

There are both benefits and costs to granting discretion to the trial judge to admit or exclude evidence. Some commentators argue that deferential appellate review of trial court discretion promotes judicial economy by reducing appellate expenditure of time and energy. ${ }^{23}$ Proponents of discretion also contend that many questions that arise in litigation, including the decision to admit or exclude evidence, require individualized and flexible decision making based on the particular context of the case; "they involve multifarious, fleeting, special, narrow facts that utterly resist generalization ...."24 Shoe-horning such decisions into rigid rules would promote error and injustice..$^{25}$ And once the need for individualized decision making is acknowledged, trial courts are in a superior position to make decisions that require taking the context and specific facts of a case into account. This serves a truth-seeking function, as "rules allowing room for a trial judge's sensitivity to the complexity and uniqueness of a particular case necessarily should promote truth more than rules providing for only mechanical application of a closed and complete system."26

The costs of discretion and deferential review are also well known. There are fears that discretionary power will be exercised arbitrarily and unfairly; that broad and ambiguous principles make evidentiary rulings unpredictable to parties preparing for trial and result in inconsistent outcomes; and that the perceived unfairness of inconsistent outcomes, or outcomes dependent on the personality of the judge one happens to draw,

23. See Rosenberg, supra note 8 , at 660 .

24. Id. at 662 .

25. See Leonard, supra note 8, at 999-1000.

26. Mengler, supra note 8 , at 460 . 
could lead to a loss of confidence in the judicial system. ${ }^{27}$ Even more troubling, perhaps, is the fear that trial judges, although closer to the context and facts of the case, simply are not capable of making the subtle and profound judgments that rules like Federal Rule 403 require. ${ }^{28}$

In the debate over trial court discretion, its cited costs and benefits both have validity; indeed, that they do probably accounts for the longevity of this debate in evidence law throughout the twentieth century. This Essay does not purport to resolve the general debate, nor even to restate in any detail its underlying cost-benefit arguments. It will, however, briefly examine these benefits and costs as they are instantiated by specific evidence rules and, in Part VI, it will draw some conclusions about the harmful consequences of the trends perceived regarding hearsay, expert testimony, and character evidence to prove conduct. We turn first, however, to the start of the century and to the great scholars of evidence law who have set the terms of this continuing debate.

II

\section{The Beginning of Reform: Thayer's Definttion of the 'LAW of EVIDENCE"}

In 1898, at the turn of the twentieth century, James Bradley Thayer, Weld Professor of Law at Harvard University, published as a single volume his essays on the law of evidence, under the title A Preliminary Treatise on Evidence at the Common Law. His aim was to clarify what general principles belonged to the subject of evidence, and to winnow out those large topics which properly belonged to other branches of law. In so doing, he hoped to prune evidence law into a field of study more easily subject to much-needed reform. Thayer intended to continue this project by writing another volume, "in similar form but of a more immediately practical character, giving a concise statement of the existing law of evidence." ${ }^{29} \mathrm{He}$ was unable to complete this second volume, as he died suddenly of heart disease in 1902 at the age of seventy-one.

In several chapters of his Preliminary Treatise, Thayer developed the narrow definition of the "law of evidence" that has shaped the field for the past one hundred years. His definition seems commonplace today: "And chiefly, it determines, as among probative matters, ... what classes of things shall not be received. This excluding function is the characteristic

27. See Leonard, supra note 8, at 991-95.

28. See Gold, supra note 8 , at 91 ("Courts have been insensitive to the complex problems of predicting human cognitive behavior posed by Rule 403."); Mengler, supra note 8 , at 461 (citing a study showing that judges have widely disparate views about what constitutes prejudicial evidence).

29. Thayer, Preliminary Treatise, supra note 5, at 5 . 
one in our law of evidence." ${ }^{30}$ Thayer's insistence that the field of evidence be limited to exclusionary rules rested on two scholarly foundations: his study of case law undertaken in the preparation of his evidence casebook and planned treatise, and his own historical research into the origins of the jury.

\section{A. Narrowing the Range of Cases that Constitute the "Law of Evidence"}

From his study of cases, Thayer was able to clear away the underbrush of cases commonly discussed in evidence texts. He found that "a vast, uncountable number in our books, while they certainly relate to evidence ... involve no point at all in the law of evidence."31 That is, they held evidence inadmissible simply because it did not relate to the principles of substantive law or to the pleadings that governed the particular case, evidence that we would consider, today, to be logically irrelevant. Important treatises prior to Thayer's, however, had treated these cases as part of the field of evidence. ${ }^{32}$ They contained lengthy analyses of categories of inadmissible and admissible evidence that were grounded on principles of relevance to the substantive law. Thayer's achievement was, thus, to focus on opinions that dealt not with "mere propositions of sound reason" 33 but with the true principles of exclusion that still define evidence law today.

Thayer also clearly identified the stout branches of law that he believed did not belong to the field of evidence. These involved common law rules developed to control the decision-making processes of juries in ways other than admitting or excluding items of proof. These rules, too, had been included in earlier evidence treatises, but Thayer was determined to separate them from the law of evidence. Chapters in his Preliminary Treatise were devoted to "Law and Fact in Jury Trials," "Judicial Notice," "Presumptions," "The Burden of Proof," and "The 'Parol Evidence' Rule." In each, Thayer demonstrated through painstakingly careful analysis of case law how "the law of evidence came to be monstrously overloaded, and was made to swallow up into itself much which belonged to other branches of law ...."34

30. Id. at 264 (emphasis added). In this passage, Thayer also described the other functions of evidence law as prescribing the manner of presenting evidence and fixing the qualifications and privileges of witnesses.

31. Id. at 269.

32. See, e.g., Thomas Starkae, A Practical Treatise on the Law of Evidence and Digest of Proofs in Civil and Criminal Proceedings (3d ed. 1830). Two of the three volumes of this treatise are devoted to explication of the elements of the substantive law (categorized alphabetically with topics such as abatement, conspiracy, and malice) and to cases dealing with the forms of proof that do or do not satisfy the legal elements.

33. Thayer, Preliminary Treatise, supra note 5 , at 269.

34. 'Id. at 4. Chapter XI of the Preliminary Treatise, entitled "The 'Best Evidence' Rule," is an excellent example of Thayer's mission to rid the field of so-called rules that did not conform to his 
It is fair to say that Thayer's definition of the field of evidence law has triumphed. The vast majority of printed material in current evidence casebooks, and the vast majority of time spent in the classroom, focus on the broad exclusionary rules that constrain the admission of items of proof and, of course, their exceptions..$^{35}$

\section{B. Understanding Evidence Law as the Child of the Jury System}

Thayer's explanation for why these exclusionary rules developed in England during the eighteenth and even seventeenth centuries was based on his research into the history of the development of the jury. The first four chapters in Thayer's Preliminary Treatise trace the development of the jury system of trial from early Germanic conceptions of proof and modes of trial, through several centuries of English law, heavily influenced by the Norman concept of royal power. The aspect of this development that most interested Thayer was the jury's evolution from a body of citizens that judged cases on the basis of facts known personally to them into a body that was required to base its decision only on evidence given publicly before a judge. ${ }^{36}$ Thayer's view of evidence law was deeply influenced by this development of the jury:

But the greatest and most remarkable offshoot of the jury was that body of excluding rules which chiefly constitute the English "Law of Evidence." If we imagine what would have happened if the petit jury had kept up the older methods of procedure ... if, instead of

definition of evidence law. Thayer described this rule as it is supposedly laid down- "the best evidence of which the case, in its nature, is susceptible, must always be produced"; discussed its treatment in the leading treatises of the era (noting that Greenleaf devotes a chapter to it consisting of sixteen sections); traced the historical origins of the term "best evidence"; analyzed the three "great illustrations" of the rule only to find that they have no common origin; argued that the term was not "in any sense... a working rule of exclusion" and that it should be discarded; but understood that it might still have weight as a general moral principle to guide the discretion of courts as that discretion was enlarged. Id. at 486, 505. In Chapter XI, Thayer appears to have foreseen an argument that has evolved as a guiding principle under Rule 403 of the Federal Rules of Evidence: that "morally speaking, the fact that any given way of proof is all that a man has, must be a strong argument for receiving it, if it be in a fair degree probative...."Id. at 507.

35. It is true that some of the topics that Thayer sought to excise from the field of evidence law are still found in modern treatises and have chapters devoted to them in current casebooks. And some would say that they belong in the field of evidence. This is so, if evidence law is understood as being all of the principles that regulate the division of power among judge, jury, and adversaries, and not just the principles of excluding probative evidence, as Thayer would have had it. This broader view prevails in current legal education because there is no other commonly taught topic of legal study in which these other principles of allocating function between judge and jury belong.

36. One important source of this requirement, according to Thayer, was the emergence of the motion for a new trial, used by judges to gain some control over the seemingly unreviewable fact-finding authority of the jury. The decision whether to grant a new trial required that the judge be apprised of the evidence that the jury had originally considered. See THAYER, Preliminary Treatise, supra note 5, at 173-74. Judges therefore began to require that any private information conveyed by a juryman to the jury had to be stated publicly in court, upon oath. Thayer cites cases from 1650,1656 , and 1702 as establishing this principle. See $i d$. at 174. 
hearing witnesses publicly, under the eye of the judge, it had heard them privately and without any judicial supervision, it is easy to see that our law of evidence never would have taken shape.... This it is-this judicial oversight and control of the process of introducing evidence to the jury, that gave our system birth; and he who would understand it must keep this fact constantly in mind. ${ }^{37}$

In another passage, whicl hints at Thayer's sense of humor as well as his profound love of his subject, he describes the end product of this method of developing evidence law:

A distinguished author tells us, at the end of a famous treatise: "The student will not fail to observe the symmetry and beauty of this brancli of the law ... and will rise from the study of its principles convinced, with Lord Erskine, that 'they are founded in the charities of religion, in the philosophy of nature, in the truths of history, and in the experience of common life."' I think that it would be juster and more exact to say that our law of evidence is a piece of illogical, but by no means irrational, patchwork; not at all to be admired, nor easily to be found intelligible, except as a product of the jury system, as the outcome of a quantity of rulings by sagacious lawyers, while settling practical questions, in presiding over courts where ordinary, untrained citizens are acting as judges of fact. ${ }^{38}$

This patchwork, Thayer believed, was full of "good sense ... that needs to be taken in hand ... and illuminated, simplified, and invigorated by a reference to general principles. ${ }^{.39}$ It is this task that Thayer left unfinished when he died in 1902. ${ }^{40}$

37. Id. at $180-81$.

38. Id. at 508-09 (footnote omitted).

39. Id. at 509 .

40. Among the papers in Thayer's study at the time of his death was a memorandum written at the start of the 1902 school year: "Have a single plan to put through. Without that the small, everyday matters eat up all the time. ... That plan must be the $2 \mathrm{~d}$ volume of Evidence." THE HARvard LAW School association, The Centennial History of the HaRvard Law School 283 (1918). In a touching memorial delivered to the Colonial Society of Massachusetts and published in the Harvard Law Review, Jeremiah Smith described his view of why Professor Thayer was unable to complete his larger treatise. He stated that the topics of the Preliminary Treatise-those subjects which "overlie and perplex the main subject"-consumed an immense amount of time in study and writing. Jeremiah Smith, James Bradley Thayer, 15 HARv. L. REv. 602, 604 (1902). Their results are of great value, Smith believed, and would not have been achieved by others in Thayer's generation. Thayer also was a perfectionist, someone who had a horror of immature authorship and premature publication. Thus his work, according to Smith, simply took him longer to complete. And finally, in an insight into Thayer's character, Smith wrote that Thayer "repeatedly, we might say almost daily, turned asidc from his own work to render assistance to other writers, often to those whose subjects were entirely outside of law." Id. at 605 . 


\section{Focusing on the General Principles of Exclusion}

A frequently quoted passage from his Preliminary Treatise reveals what Thayer regarded as the two most fundamental propositions of a rational system of evidence: first, "a principle which forbids receiving anything irrelevant, not logically probative," and second, "another precept ... that unless excluded by some rule or principle of law, all that is logically probative is admissible." ${ }^{41}$ These propositions are another of Thayer's triumphs, recreated as the rule of relevance in every major reform effort of the twentieth century. ${ }^{42}$

In the development of the common law, however, relevance had not been seen as the bedrock requirement of admissibility to which the various exclusionary principles were applied. Thus, the loss of relevant evidence through exclusionary principles was not seen as requiring an explicit justification. Rather, in typical common law fashion, "[w] hat has taken place ... is the shutting out by the judges of one and another thing from time to time; and so, gradually, the recognition of this exclusion under a rule." ${ }^{\prime 3}$ This common law tradition would be improved, Thayer beheved, if these two fundamental propositions of relevancy could be preeminent and always kept in mind.

Thayer concluded his Preliminary Treatise with a very brief discussion of the principles of exclusion that he identified as the proper subject of study and reform. The first he referred to as a set of large and inexact principles whereby the judge has the discretionary authority to exclude evidence that is only "slightly" or "remotely" relevant, and which may "complicate the case," or "confuse, mislead, or tire the minds" of the jury. "Then Thayer only sketched a description of the principle forbidding the admission of hearsay ${ }^{45}$ and the system of exceptions to the rule of exclusion-dying declarations in homicide cases, parish records, reputation, and ancient writings being among the oldest exceptions. ${ }^{46}$ Thayer presented an even briefer discussion of the two other chief principles of exclusionforbidding the giving of opinion evidence and of character evidence. $\mathrm{He}$ traced the origims of both exclusionary principles to the jury system of trial. About the opinion rule he wrote, "It was for the jury to form opinions, and draw inferences and conclusions, and not for the witness. He was merely to bring in to the jury, or the judge, the raw material of fact, on which their

41. Thayer, Preliminary Treatise, supra note 5, at 265 .

42. See infra notes 68,101 and accompanying text.

43. Thayer, Preliminary Treatise, supra note 5, at 265.

44. Id. at 516.

45. "When juries, who were themselves, originally, witnesses as well as triers, came to be helped regularly by the testimony of other witnesses, it was only by such as personally knew the truth of what they were saying, and not by witnesses who only knew what some one else had said to them." Id. at 519.

46. Id. at 519-21. 
minds were to work. ${ }^{247}$ Of the character rule, Thayer had even less to say. It was a modern rule, limited to English-speaking courts, which "forbids the use of a person's general reputation or actual character, as a basis of inference to his own conduct." ${ }^{48}$

These great principles of exclusion-insufficient probative value, hearsay, opinion, and character-remain the primary substantive concerns of evidence law today. Thayer did not dispute the substantive wisdom of these exclusionary rules in his Preliminary Treatise. Rather, his criticism was directed at "the multiplicity and rigor of [common law] rules and exceptions to rules," which robbed courts of flexibility and creativity in making decisions to admit or exclude evidence. ${ }^{49}$

\section{III}

\section{Thayer's View of Judicial Discretion: The Cure for the General ILLS OF EVIDENCE LAW}

Thayer advocated the simplifying and restating of evidence rules by courts, not by the legislature. He aspired to a system of simple rules, "aiming straight at the substance of justice, not nice or refined in its details, not too rigid, easily grasped and easily applied." ${ }^{0}$ Legislation might be necessary, he foresaw, to grant courts this broad authority. Lawyers, he thought, were the greatest obstacle to these efforts because of the conservative attitude of their profession toward untried change. ${ }^{51}$

Essential to the reform of evidence law would be the broadening of judicial discretion in applying the rules, an expansion of judicial control over the "eager lawyer in his endeavors to press to an extreme the application of the rules," ${ }^{52}$ and a deferential standard of appellate review..$^{53}$ Thayer believed that the American system should resemble the English system, in which the trial judges used their influence to check controversies over points of evidence, and where appellate courts construed the rules of evidence freely, "in a large way," and declined to interfere with the rulings of lower courts except "in cases of abuse or clear and important

47. Id. at 524 .

48. Id. at 525 .

49. Id. at 527. The common law of evidence made it difficult for judges to determine, "in the decision of new questions, whether to give scope and extension to the rational principles that lie at the bottom of all modern theories of evidence, or to those checks and qualifications of these principles which have grown out of the machinery through which our system is applied, namely, the jury." Id.

50. Id. at 529 .

51. Thayer quotes approvingly from an address by Judge Theodore Bacon to the graduating class of the Yale Law School in 1896: "[N]o class in modern society is more conservative, more timid in promoting, more resolute in resisting, alterations in existing law, than the body of which we are members." Id. at 532.

52. Id. at 528 .

53. Id. at 516 . 
error . . .."54 In America, claims of evidentiary error were raised on appeal in the abstract, leading to overly technical rulings that fostered "delay and chicane" rather that allowing the appellate court to focus on "the general justice of the case which the more elastic procedure of the English courts so commonly allows ...."ss This enlargement of trial court discretion, based on the particular facts of each case, was justified, in Thayer's view, by the rough and tumble of the trial process. Shortness of time and pressures of adversarial competition demanded simplified rules, in the nature of general principles, "to guide the sound judgment of the judge, rather than minute rules to bind it." 56

In his Preliminary Treatise, Thayer was not able to develop his ideas about how to inject trial court discretion into a system of evidence rules. ${ }^{57}$ His abbreviated comments do indicate his fundamental commitment to giving the trial court greater freedom to admit or exclude relevant evidence through flexible consideration of its probative value rather than through application of more rigid and categorical rules. For example, with regard to the hearsay rule, as the exceptions multiplied and expanded, Thayer recognized a tension that is still being addressed by hearsay reformers today: whether to honor the historical theory of the common law cases that carved out specific doctrinal exceptions to the hearsay ban, or to derive a general theory of admissibility from the first principle that "whatsoever is relevant is admissible." ${ }^{58} \mathrm{He}$ suggested, but did not develop, a theory of admissibility based on circumstantial reliability, which clearly would have enlarged the discretion of the court:

[H] earsay statements often derive much credit from the circumstances under which they are made... credit amply enough in point of reason to entitle them to be received as evidence, when once the absence of the perceiving witness is accounted for; and it

54. Id. at 534. "[T] there should be an abuse, in order to justify a review of them by an appellate court." Id. at 530 .

55. Id. at 529 .

56. Id. at 530 .

57. In concluding Chapter XII, Thayer listed eight great principles that should guide trial judges in managing cases that are tried to juries. Three of these relate to rules of exclusion: (1) The jury must "so far as possible" see and hear the witnesses whose statements they are asked to believe, (2) the jury must also not be forced to listen to evidence that will unduly delay the case, or confuse or mislead them, and (3) the jury may hear opinions of persons "specially qualified, wherever they are likely to be materially helped by it." Id. at 536 . Thayer's remaining five great principles dealt with taking testimony from witnesses under oath, subject to cross-examination; the inspection of writings by the jury; the taking of testimony in public, in the presence of the court and all parties; the required showing of the execution of solemn documents and their construction; and the power of the court to review and set aside the verdict of the jury to prevent gross injustice and to secure conformity to the rules of law and sound reason. Id.

58. Id. at 522 . 
would in reason have been quite possible to shape our law in the form that hearsay was [thus] admissible $\ldots . .{ }^{59}$

With regard to opinion evidence, Thayer derived a principle of admissibility that rested on judgments of probative value in the particular case: "[T]here is ground for saying that, in the main, any rule excluding opinion evidence is limited to cases where, in the judgment of the court, it will not be helpful to the jury." ${ }^{10} \mathrm{He}$ was frank about the unreviewability of decisions under such a rule: "such a principle must allow a very great range of permissible difference in judgment... conclusions of that character ought not, usually . . . be regarded as subject to review by higher courts." ${ }^{11}$ When nondeferential appellate review is allowed, according to Thayer, courts rule with "much too heavy a hand" and the number of decisions "is most unreasonably swollen." ${ }^{\text {2 }}$ Finally, Thayer appeared to accept a general rule excluding character evidence to prove conduct. However, he justified such a rule by balancing the evidence's probative value against its potential dangers: "Undoubtedly, as a mere matter of reason, it often affords a good basis of inference; and, on the other hand, often, besides tending to surprise a man, and to subject him to the operation of prejudice and malice, it is quite too conjectural and too slight to be safely used...."

In response to any objection that judges may not be fit for the broad discretion he advocated for them, Thayer expressed what we now would call naive confidence in the fitness of higher federal and state courts. ${ }^{64} \mathrm{He}$ also emphasized the wide degree of discretion already given to judges in sentencing, contempts, motions, rules of presumptions and judicial notice, as well as in conducting trials generally. ${ }^{65}$ In short, Thayer resolutely trusted trial judges to exercise their judgment in admitting and excluding evidence, much as they controlled many other aspects of trial. The general principles that he advocated, basing admission and exclusion decisions on case-specific judgments of probative value and limiting appellate review of those decisions, influenced reform efforts for the next one hundred years.

59. Id. at 523 .

60. Id. at 525. If special training and knowledge were needed, then skilled witnesses should be allowed to give their opinions. Otherwise, lay opinions were helpful to the jury only when they were based on "special opportunities of observation." Id. at 524.

61. Id. at 525 .

62. Id.

63. Id.

64. See id. at 537. Where judges were not fit, Thayer suggested that the "breed of judges" should be changed, noting that in most states where judges were without life tenure, this could be "quickly and easily" accomplished. Id. Here Thayer's prescription seems remarkably naive.

65. See id. 


\section{IV}

The Model Code of Evidence: Morgan v. Wigmore

John Henry Wigmore and Edmund M. Morgan, the two leading figures in the next generation of evidence scholars and reformers, were deeply committed to Thayer's insights into evidence law. Wigmore, Professor of the Law of Evidence in the Law School of Northwestern University, studied under Thayer and published, in four volumes, A Treatise on the System of Evidence in Trials at Common Law $w^{66}$ two years after Thayer's death. The Treatise is dedicated to Thayer; its Preface acknowledges that Thayer's historical work has "set the example and marked the lines for all subsequent research in this part of the subject." ${ }^{967}$ In Chapters Two and Three of Book I of Volume I, Wigmore presents Thayer's two fundamental propositions as the axioms upon which the modern evidence system rests: "[n]one but facts having rational probative value are admissible" and "[a]11 facts having rational probative value are admissible, unless some specific rule forbids." 68

Morgan, the other great figure, studied at Harvard Law School after Thayer's death, but his scholarship was imbued with the legacy of Thayer's thinking and teaching. In 1934, Morgan, then a Professor of Law at Harvard, joined Professor John M. Maguire in revising Thayer's leading casebook into Morgan and Maguire, Cases on Evidence, a book that, with new revisers and authors, is now in its ninth edition. Morgan's Foreword to the Model Code contains several references to Thayer's contributions to the field, and wholly adopts Thayer's insight that the American law of evidence is concerned with the admissibility, not the weight, of proof. ${ }^{69}$ In their approaches to drafting rules of evidence, however, Wigmore and Morgan not only disagreed but sharply clashed.

\section{A. Two Different Approaches to Reform}

During the first thirty years of the twentieth century, both Wigmore and Morgan perceived the almost desperate need to rationalize the law of evidence in line with Thayer's great insights into the primacy of relevance. They also agreed on the need to protect the trial judge's application of the law from detailed scrutiny by appellate courts. Their general approaches to reform, however, differed significantly. Wigmore was convinced that existing precedents could be analyzed, evaluated and reconciled into majority rules for which sound justification could be found. Morgan had no

66. John Henry Wigmore, A Treatise on the System of Evidence in Trials at Common LAW (1904) [hereinafter WIGMORE ON EVIDENCE].

67. Id. at xii.

68. Id. at 31,34 .

69. See Edmund M. Morgan, Foreword to Model CodE of Evidence 1 (1942). 
such confidence in the rationality of existing precedent and wanted to begin anew with the formulation of broad principles, drafted as a code.

Wigmore's approach is exemplified in his Treatise, which he did not intend as a vehicle for law reform. Rather, he had three ambitious purposes in mind:

[F]irst, to expound the Anglo-American law of Evidence as a system of reasoned principles and rules; secondly, to deal with the warring mass of judicial precedents as the consistent product of these principles and rules; and, thirdly, to furnish all the materials for ascertaining the present state of the law in the half a hundred independent American jurisdictions. ${ }^{70}$

Yet reform was not far from his mind. By searching out and emphasizing the most generally accepted reasons for the rules of exclusion, Wigmore sought to "save the law for a living future."71 He set forth the most influential and lucid judicial exposition of these reasons; aligned the precedents from state and federal courts, both supporting and opposing the majority view; and traced "[t]he chameleon-like application of the rules" to their source "by the use of copious cross-references." " Wigmore's monumental work provided knowledge of what the law was and laid the foundation for future reform efforts, including his own version of a code published in 1910 and republished in its second edition im 1935. ${ }^{73}$

Despite the Treatise's popularity and rationalizing effect, it did not satisfy the critics of evidence law, including Morgan. In the early 1930s, the American Law Institute (ALI) refused to undertake a Restatement of the law of evidence, principally because

the Rules themselves in numerous and important instances are so defective that instead of being the means of developing truth, they operate to suppress it.... [A] Restatement of the Law of Evidence would be a waste of time or worse; ... what was needed was a

70. Wigmore on EVDIENCE, supra note 66, at vii. The historical and legal context out of which Wigmore's Treatise emerged is described in CharLes Alan WRIGHT \& KENNETH W. GRAhAM, JR., 21 Federal Practice and Procedure $\S 5001$ (1977). They write that Wigmore "saw himsclf as rescuing the basically sound common law rules from the embrace of the rabble that Jacksonian democracy had placed upon the bench." Id.

71. WIGMORE ON EVIDENCE, supra note 66, at viii.

72. Id. at $\mathrm{x}$. In his Preface to Volume $\mathrm{I}$, Wigmore quotes a critique of the present state of the law made by a president of the American Bar Association:

A judge may decide almost any question any way, and still be supported by an array of cases.

Cases are our counters, and there are no coins. Our legal arguments are for the most part a mere casino-like matching and uumatching of cases, involving little or no intellectual effort. The law is ceasing to be a question of principles, and is becoming a mere question of patterns.

Id. at ix.

73. JOHN HENRY Wigmore, Wigmore's CODE OF the Rules of EVIDENCE IN TRIALS AT LAW (2d ed. 1935). 
thorough revision of existing law. A bad rule of law is not cured by clarification. ${ }^{74}$

Morgan described the existing law as follows:

The rules of evidence have been developed in myriads of cases, wherein the later judges have felt themselves bound by the doctrine of stare decisis to adhere to the pronouncements of their predecessors but bound also to avoid the absurdities which the simple application of these pronouncements would produce.... [T]hey have engrafted qualifications, refinements and exceptions upon the earlier rules, so that the law of evidence has grown irregularly and in haphazard fashion, one rule seeming to have no relation in reason to another. ${ }^{75}$

The ALI did begin a study of evidence law with a view to its revision in 1939, supported by a grant of $\$ 40,000$ from the Carnegie Corporation. The Reporter for the project, which came to be known as the Model Code of Evidence, was Professor Morgan, and the committee members included distinguished professors, judges, and a single practitioner. Wigmore was asked to be "Chief Consultant," heading a hist of over sixty consultants. He did not attend meetings of the committee, but made his views, comments, and criticisms known to the group. Although they had differences of opinion over some matters of substance, it was the form of the code that provoked the sharpest disagreement between Wigmore and Morgan. Not surprisingly, underlying this dispute about form was a critical difference of opinion about the proper substance of trial court discretion.

\section{B. A Catalogue, a Creed, or a Code?}

Under Morgan's guidance, the ALI proposal took the form of a code, or "a series of rules in general terms covering the larger divisions and subdivisions of the subject without attempting to frame rules of thumb for specific situations ...."76 Morgan believed that adoption of such general rules with some guiding standards would make the trial judge's rulings reviewable only for abuses of discretion: "This leaves . . . much room for the exercise of a sound judgment; it does not hamper [the judge] with detailed restrictions, and tends to discourage useless appeals."77

After the first Tentative Draft of the ALI Code was circulated in 1940, Wigmore rejected the idea of general rules and proposed a different version, similar to his own previously published code. Wigmore's version entailed exactly the kind of detailed instructions and restrictions that Morgan had denounced. Wigmore wrote that the new rules "must not be content

\footnotetext{
74. Model Code, supra note 4, at viii.

75. Morgan, supra note 69, at 5 (1942).

76. Id. at 13 .

77. Id.
} 
with abstractions, but must specifically deal with all the concrete rules, exemplifying the application of an abstraction, that have been passed upon in a majority of jurisdictions; the Code specifically either repudiating or affirming these rules." ${ }^{78}$ Wigmore believed that his version of a code would provide specific and necessary practical guidance for practicing attorneys, and that a detailed set of concrete rules, rather than general principles, was required:

If the objection be made that the law of Evidence should no longer remain a network of petty detailed rules, the answers are, first, that both Bench and Bar need their guidance in order that a normal routine be ordinarily followed for speedy dispatch at trials without discussion; secondly, that the Bar needs them in order to prepare evidence for trial along normal expected lines ... . ${ }^{79}$

It is difficult to describe here the microscopic detail of Wigmore's code, and to contrast it with the work of Morgan and his committee. Wigmore's code of 241 rules, each containing numerous articles, ran over five hundred pages; the Model Code, with 116 rules was less than three hundred printed pages (including lengthy comments). A concrete example may help to convey the difference in form and, in consequence, substance. In Morgan's draft, the Best Evidence Rule (Rule 602) required parties to produce original writings unless certain exceptions applied. Model Rule 602 defined those exceptions simply and broadly: if the original was "now unavailable for some reason other than the culpable negligence or wrongdoing of the proponent ... or ... it would be unfair or inexpedient to require the proponent to produce the writing." ${ }^{\circ 0}$ This rule provided general standards-unavailability, unfairness, or inexpedience-that the trial court could administer on a case-by-case basis. Wigmore thought that these "curt" paragraphs offered too little guidance "on an everyday subject of wide scope for which several 'rules of thumb' have long been worked out by experience to guide the practitioner in preparation for trial." ${ }^{81}$ Thus, in his code, Wigmore spelled out in ten articles of Rule 139, requiring six pages of printed text, the precise circumstances where nonproduction of an original writing would be excused. ${ }^{82}$ Each of these circumstances was specifically and technically defined, loaded with words subject to varying interpretation.

Morgan described Wigmore's approach as a catalogue, attempting to "canvass all the situations in which pertinent questions have been answered

78. John H. Wigmore, The American Law Institute Code of Evidence Rules: A Dissent, 28 A.B.A. J. 23, 23 (1942).

79. ALI, Code of Evidence, Tentative Draft No, 1112 (1940) (Appendix: Statement by John H. Wigmore).

80. MODEL CODE, supra note 4 , at 298.

81. Wigmore, supra note 78 , at 26.

82. WIGMORE, supra note 73, at 228-34. 
by the courts and to devise a mandate to the trial judge for each case" which would "produce a long, unwieldy enactment which would be in effect a restatement of the law of evidence .... It would give the restatement a legislative form, make it rigid and hamper the normal growth of the law." 83

Wigmore understood these risks that had plagued the common law, but thought that his rules could be "only discretionary, not mandatory,""guides, not chains" despite their detailed nature. By legislative fiat Wigmore intended to "forbid the review of the trial judge's application of these rules except in extreme imstances. ..." ${ }^{84}$ and thus to control the inevitable tendency of appellate courts to re-apply and re-interpret such extensive and detailed text.

As must be obvious, underlying Wigmore and Morgan's debate over form were the deeper issues of substance. Could trial courts really be trusted with "discretion" to admit or exclude evidence? How much guidance should the rules provide to control the exercise of that discretion? Wigmore clearly sought to shape, even constrain, trial court discretion through rules that embodied his own detailed instructions. Morgan believed that discretion required sound judgment, guided by broad standards. Another ALI consultant, Judge Charles E. Clark, proposed that trial judges be free to exercise an even more liberal form of discretion than was envisioned by Morgan. He advocated that the rules should be extremely broad and general grants of power, with all details left to the discretion of the trial judge. ${ }^{85}$ Morgan summed up the victory of his position in this threeway debate in the following terms: "[T]he choice is between a catalogue, a creed, and a Code. The Institute decided in favor of a Code." ${ }^{86}$

\section{Judicial Discretion as Adopted by the Code}

The Model Code of Evidence included some radical changes in the existing law of evidence. For example, it abolished all disqualifications of witnesses, and provided that hearsay would be admissible if the declarant was either made available for cross-examination or found to be unavailable. ${ }^{87}$ The Code was also designed, as Morgan quite frankly announced, to

83. Morgan, supra note 69 , at 12 . Wigmore predicted that the practicing bar would not accept the Code. See Wigmore, supra note 78, at 28.

84. Wigmore, supra note 78 , at 26.

85. Judge Clark's position is only briefly reported in the proceedings of the ALr. See 26 A.B.A. J. 476 (1940). Morgan thought that Judge Clark's approach was so open-ended and abstract that it "would serve a useful purpose only in case the decision of the trial judge is to be final and not subject to review. Otherwise each application of the general principle to a new situation would invite appeal." Morgan, supra note 69 , at 13 . Wright and Graham contend that battles over codification, and over the control that a code would impose on judges, were part of the larger political contest between Jacksonian democracy and elitist, Progressive values. WRIGHT \& GRAHAM, supra note 70, at $\$ 5005$.

86. Morgan, supra note 69, at 12-13.

87. See MOdEl CODE, supra note 4, Rules 9 and 503. 
restore the trial court judge's "historic role as master of the trial,"88 at the expense of both the appellate courts and the parties. Several of the Code's rules illustrate this point. Rule 105 greatly enlarged the power of the judge to control such matters as the order in which evidence should be presented, the number of witnesses who could testify to a material matter, the use of leading questions, and the scope of cross-examination.$^{89}$ Rule 8 allowed the judge to sum up the evidence and comment on the weight of the evidence and the credibility of the witnesses, as was the practice in England. ${ }^{90}$ Rules 6 and 7 provided that no reversal could be ordered for evidentiary error unless the improper ruling probably had a substantial influence in producing the result." Thus "there runs through the whole Code the theory that the trial judge['s] . . . action is final except where an abuse of his discretion results in material prejudice to the substantial rights of the losing litigant."92

The Code granted explicit discretion to the trial judge in several areas. Rule 303 gave the judge discretion to exclude evidence on grounds quite similar to those articulated in Federal Rule 403: if probative value was outweighed by the risk of undue consumption of time, substantial danger of undue prejudice, confusing the issues, misleading the jury, or unfair surprise, then the evidence would not come in. Morgan's Foreword also noted the court's discretion in Rule 602, which provided for admission of secondary evidence of an unavailable writing, ${ }^{93}$ and Rule 519, which excluded certain documentary evidence, in the discretion of the judge, if the adversary had not been furnished with copies. ${ }^{94}$

The reaction of the conservative practice bar to the Model Code, as Wigmore predicted, was hostile. In particular, the enhanced power of the trial judge disturbed many lawyers. ${ }^{95}$ Several members of the ALl

88. Morgan, supra note 69 , at 13.

89. Rule 105 gave the trial judge "discretion" to determine a long list of powers and prefaced this list with the following: "The judge controls the conduct of the trial to the end that the evidence shall be presented honestly, expeditiously and in such form as to be readily understood ...." MODEL CODE, supra note 4, Rule 105. Wigmore was scathing in his criticism of this Rule, as the term discretion was not further defined:

Must we not infer that the draftsmen did not themselves have clearly in mind what they meant by "in his discretion determines"? - When it is recalled that there are upwards of 5000 court-of-record trial judges, and that perhaps $20 \%$ of them come newly to the Bench every 6 years or so, is it not probable that in those proposed large areas of "discretion" the Law of Evidence will suffer, not a re-form, but a relapse into that primal condition of chaos, described in Genesis 1:2, when the Earth "was without form and void"?

Wigmore, supra note 78, at 24.

90. See MODEL CODE, supra note 4, Rule 8.

91. MODEL CODE, supra note 4, Rules 6 and 7.

92. Morgan, supra note 69 , at 15 .

93. See supra text accompanying note 80 .

94. MODEL Code, supra note 4, Rule 519.

95. Wright and Graham suggest that "[m]lost lawyers were probably scared to death" by Morgan's Foreword to the Model Code in which he frankly announced the Progressive vision of taking 
Advisory Committee, including J. Russell McElroy, Presiding Judge of the Tenth Judicial Circuit of Alabama, published articles defending the Code. ${ }^{96}$ McElroy's article sought to dispel concerns about the general discretion vested under Rule 303, in particular its use to exclude facts relevant to support or impair the credibility of witnesses, and about the trial judge's power to permit cross-examination beyond the scope of the direct examination. ${ }^{97}$ These defenses were not persuasive, however, and the Model Code of Evidence was not adopted in a single American jurisdiction.

The influence of the Model Code was, nevertheless, felt by succeeding generations of evidence law reformers, both positively and negatively. Morgan's goal of simplifying the job to be done by trial judges, while still providing substantive guidance for their admission and exclusion decisions, was carried forward into the Federal Rules of Evidence. However, some of the Model Code's most radical departures from the common law, including Morgan's vision of the trial court judge as "master of the trial," were abandoned. The drafters of the Federal Rules, eager not to repeat the failure of the Model Code, settled for rules presenting merely an "authoritative compilation of the [existing] case law ...." At the same time, the drafters also included important grants of trial court discretion.

\section{$\mathrm{V}$}

Thayer's MOdern INCARNation: JUdicial DisCRetion IN THE Federal RULES OF EVIDENCE

From start to finish, it took fourteen years to enact the Federal Rules of Evidence. Enactment also required intense professional and political activity, the impetus for which was the failure both of the Model Code and of all subsequent reform efforts aimed at enacting a uniform law of evidence throughout the United States. ${ }^{99}$ Successive Advisory Committees on the Rules of Evidence were appointed by the Judicial Conference of the United States, starting in 1961. The Committees first studied the question of the feasibility of uniform federal rules, then developed a Preliminary Draft, and ultimately produced a Revised Draft, which they sent to the United States Supreme Court in 1970. The Court ordered that the Draft be widely published, causing Congress to intervene in 1971. Congressional hearings created several controversies, primarily over the Rules providing for extensive governmental privileges, and led to some significant

\footnotetext{
a few "good men" and giving them lots of discretionary authority. 21 WRIGHT \& GRAHAM, supra note 70 , at $\$ 5005$.

96. See J. Russell McElroy, Some Observations Concerning the Discretions Reposed in Trial Judges by the American Law Institute's Code of Evidence, MODEL CODE, supra note 4, at 356.

97. See id. at $360,365,368$.

98. 21 WRight \& Graham, supra note 70 , at $\$ 5007$.

99. A brief and engaging history of the drafting of the Federal Rules is contained in 21 WRIGHT \& GRAHAM, supra note 70 , at $\$ 5006$.
} 
revisions. Congress finally adopted the Federal Rules in December, 1974, and the Rules took effect on July 1, 1975. ${ }^{100}$

The Federal Rules are imbued with Thayer and Morgan's legacy. At their core are the two fundamental propositions that Thayer expounded in the Preliminary Treatise: no evidence that is not relevant shall be admitted, and all relevant evidence shall be admitted unless specifically excluded by a Rule or other legislative act. ${ }^{101}$ The echoes of Thayer's urgings towards greater trial court discretion are also immediately apparent. Federal Rule 403, the general grant of discretion to exclude lists criteria that are virtually identical to those discussed by Thayer and recapitulated by Morgan in Model Code Rule 303, but it sets the higher standard that dangers must "substantially" outweigh probative value to justify exclusion. ${ }^{102}$ Federal Rule 102 exhorts judges to construe these Rules "to secure fairness in administration, elimination of unjustifiable expense and delay, and promotion of growth and development of the law of evidence to the end that the truth may be ascertained and proceedings justly determined." ${ }^{103}$ This language has also been thought by some commentators to provide a general justification for a system of rules that provides judges with considerable flexibility and discretion. ${ }^{104}$. Rule 103 establishes the protection for the finality of trial judge rulings advocated by Thayer and proposed in Rules 6 and 7 of the Model Code: "Error may not be predicated upon a ruling which admits or excludes evidence unless a substantial right of the party is affected...."105

Missing from the Federal Rules, however, is Morgan's vision of the enhanced authority of the trial judge to control the process of trial, ${ }^{106}$ but the text of some Federal Rules does specifically authorize the use of discretion in admission and exclusion decisions. In an article published ten years after the Rules' adoption, Professor Waltz analyzed both explicit and more coded references to discretion. ${ }^{107}$ Writing in response to fears that "the federal model provides for an unprecedented degree of flexibility in evidence-taking," 108 Waltz concluded that such concerns were not justified.

\footnotetext{
100. See Act of Jan. 2, 1975, Pub. L. No. 93-595, 88 Stat. 1926 (1975).

101. See FED. R. Evid. 401, 402.

102. See supra text accompanying note 10 .

103. FED.R. EvID. 102.

104. See, e.g., Mengler, supra note 8, at 438-39.

105. FED. R. Evid. 103. Under the concept of harmless error, trial judgcs are insulated from reversal; harmless errors are those errors found highly probable of not affecting the outcome. See, e.g., United States v. Harrison-Philpot, 978 F.2d 1520, 1527 (9th Cir. 1992) (citing United States v. Brown, 880 F.2d 1012, 1016 (9th Cir. 1989)).

106. There is no grant of overall authority, such as Rule 105 of the Model Code provided. See supra text accompanying note 89.

107. See Waltz, supra note 8, at 1109-19.

108. Id. at 1099.
} 
Waltz analyzed those Rules in which the term "discretion" appears, ${ }^{109}$ and those that seemed to mandate the exercise of discretion by the use of specific terms such as "in fairness," "in the interests of justice," and "may."110 Overall, Waltz concluded: "most of the grants of judicial discretion in the Rules are accompanied by appropriate guidelines to which the courts are, by and large, adhering."

An excess of discretion can be perceived, however, in recent developments regarding several bright-line categorical Federal Rules that were intended to restrict the discretion of the trial judge. Most important among these are the hearsay rule of exclusion, ${ }^{112}$ the categorical exceptions that provide for the admission of hearsay, ${ }_{1}^{113}$ and the categorical requirement that specific acts prove something other than action in conformity with character. ${ }^{114} \mathrm{~A}$ trend toward an excess of trial court discretion under these bright-line rules appears in amendments to the Federal Rules, in Supreme Court interpretation of existing Rules, and in the tendency for trial courts to ignore the categorical limits placed on the admission of evidence. It is appellate court deference to trial court decision making that makes this trend possible. Thus, it might be thought to fulfill the vision of Thayer, Wigmore, and Morgan. But does it? This Part examines where and how excess discretion has been introduced into the Federal Rules in the areas of hearsay, expert opinion testimony, and specific acts used to prove action im conformity with character. Part VI then discusses the costs of excess discretion, which include a potential threat to basic institutional values in our system of justice.

109. Four of these Rules involve procedural matters rather than evidence-taking; Rule 608(b)'s grant of discretion in the admission of extrinsic proof of specific acts to prove character for untruthfulness for impeachment purposes "has most frequently been used to exclude rather than admit," and "Rule 706, relating to court appointed witnesses, is rarely used." Id. at 1109.

110. See id. at 1109-19.

111. Id. at 1119. The discretionary language in some Federal Rules actually tempers the radicalism of the more bright-line rules of admission proposed in the Model Code. Code Rule 401, for example, provided for the admission of lay and expert opinion with no limiting discretionary standard, whereas Federal Rules 701 and 702, respectively, require that the trial must find that the lay opinion is "helpful" and that the expert opinion "will assist" the trier of fact. Code Rule 106 limited proof of convictions to impeach a witness's credibility to those crimes involving dishonesty or false statement, whereas Federal Rule 609 permits the admission of all felonies under standards of discretion. Code Rule 503 categorically admitted all hearsay statements of unavailable and testifying declarants, whereas the Federal Rules contain neither broad exception and created, instead, the flexible and discretionary residual exception.

112. Federal Rule of Evidence 801 excludes as hearsay those out of court statements offered to prove the truth of the matter asserted, and provides a fact-based "intent to assert" test to be used to apply this exclusionary standard to out of court conduct. See FED. R. Evid. 801.

113. Federal Rules of Evidence 801(d), 803, and 804 contain the categorical definitions of those statements that may be admitted as exemptions or exceptions to the rule of exclusion. Only two of these exceptions, those admitting business and public records, permit the trial judge to exclude the categorically admitted hearsay under the more discretionary standard of "untrustworthiness." See infra text accompanying note 115 for a discussion of the discretionary residual exception.

114. See infra text accompanying note 147 . 


\section{A. The Use of Discretion Erodes Categorical Constraints in the Admission of Hearsay}

The Federal Rules of Evidence broke new ground when they granted trial courts the ability to admit hearsay under a discretionary, noncategorical basis. What is now Rule $807,{ }^{115}$ the residual, or catchall, exception, was recognized by its Advisory Committee drafters to be a bold experiment; but not too bold, however, as the Advisory Committee sought to limit its use to "exceptional cases" where the hearsay had a high degree of both probativeness and necessity. It was not to be used to create "major judicial revisions of the hearsay rule, including its present exceptions." 116 As has been well documented, however, courts have not been able to hold to the Advisory Committee's admonition. A study by Professor Myrna Raeder in 1992 showed that hearsay had been admitted under the residual exception in over half of the instances in which it was offered. ${ }^{117}$ Professor Raeder also documented that the residual exception was both expanding the doctrinal limits of the existing exceptions and masking "the introduction of other types of hearsay which defy admission under the specific exemption categories." 118 She concluded that appellate decisions are ineffective in stopping the "total erosion of the hearsay rule by judicial discretion ... because they review the admission of such hearsay for abuse of discretion and harmless error." 119

Trial courts also inject their discretion into decisions made to admit or exclude hearsay under the categorical exceptions. Another study, conducted by the author in 1992, found that trial courts used several techniques to expand the admission of hearsay statements, including explicit consideration of the credibility of the hearsay statement through use of

115. Rule 807 provides:

Residual Exception.

A statement not specifically covered by Rule 803 or 804 but having equivalent circumstantial guarantees of trustworthiness, is not excluded by the hearsay rule, if the court determines that (A) the statement is offered as evidence of a material fact; (B) the statement is more probative on the point for which it is offered than any other evidence which the proponent can procure through reasonable efforts; and $(\mathrm{C})$ the general purposes of these rules and the interests of justice will best be served by admission of the statement into evidence. However, a statement may not be admitted under this exception unless the proponent of it makes known to the adverse party sufficiently in advance of the trial or hearing to provide the adverse party with a fair opportunity to prepare to meet it, the proponent's intention to offer the statement and the particulars of it, including the name and address of the declarant.

FED. R. Ev1D. 807.

116. S. REP. No. 93-1277, at 20 (1974), reprinted in 1974 U.S.C.C.A.N. 7051, 7066.

117. See Myrna S. Raeder, Commentary: A Response to Professor Sivift, 76 MiNN. L. Rev. 507, 514 (1992).

118. Id. at 515-16. See also Randolph N. Jonakait, The Subversion of the Hearsay Rule; The Residual Hearsay Exceptions, Circumstantial Guarantees of Trustworthiness, and Grand Jury Testimony, 36 CASE W.REs. L. Rev. 431 (1986).

119. Raeder, supra note 117 , at 517. 
"circumstantial guarantees of trustworthiness." 120 As examples of the overt recourse to discretion to admit hearsay that did not quite fit into a categorical exception, the study cited statements of alleged child abuse victims offered under the excited utterance exception, statements made with substantial contemporaneity offered as present sense impressions, and statements made under stress offered as excited utterances. ${ }^{121}$ In each instance, the courts explicitly stated that the testimony should be admitted because it was "trustworthy," or because its fit within the categorical exception was "buttressed by the intrinsic rehability of the statements."

When judges use such a discretionary standard in admitting hearsay, primarily substituting the court's estimates of the hearsay declarant's trustworthiness for categorical "fit," categorical constraints disappear. This raises the spectra of the outright evaluation of credibility by judges on a case-by-case basis, inconsistency in outcomes, and potential for unfairness. It would equally violate categorical constraints for the trial court to use a finding of "untrustworthiness" to justify exclusion of a hearsay statement that otherwise fits an exception. ${ }^{123}$ It is, of course, impossible to know how frequently courts explicitly rely on "trustworthiness" to justify admission in such circumstances. The vast majority of such evidentiary decisions do not find their way into any official record. When they do, and the appellate court either finds no error, or no reversible error, there is little to deter such continuing erosion of the categorical constraints.

120. Eleanor Swift, The Hearsay Rule at Work: Has It Been Abolished De Facto by Judicial Decision?, 76 MinN. L. Rev. 473, 491 (1992). The other two techniques involved new interpretations of categorical terms to respond to recurring fact patterns that present useful, and often necessary, hearsay, and the liberal application of standard categorical terms. The study concluded that while this behavior did not amount to abolition of the rule against hearsay, "it threatens to subvert what remains of the categorical structure" of the exceptions. Id. at 490.

121. See id. at 491,492 n.57, 495 \& n.69.

122. Id. at 491, 492 n.57. A study of Illinois state court opinions reveals that explicit consideration of "motive to fabricate" has been injected into the application of the spontaneous declaration exception, often resulting in the admission of hearsay statements that do not satisfy the exception's explicit requirement of "absence of time to fabricate" if no such motive is found. See Peter F. Valori, The Meaning of "Bad Faith" Under the Exceptions to the Hearsay Rule, 48 U. MIAMI L. REv. 481, 494-95 (1993).

123. It has been argued that the Supreme Court, in United States $v$. DiNapoli, imported a requirement of "trustworthiness" into the text of Federal Rule 804(b)(1), excluded the hearsay statement proffered by the defendant, and thereby engaged in judicial revision of the hearsay rule. See Valerie A. DePalma, United States v. DiNapoli: Admission of Exculpatory Grand Jury Testimony Against the Government Under Federal Rule of Evidence 804(b)(1), 61 BrooK. L. REv. 543, 588 (1995). And a line of cases originating with the Ninth Circuit opinion in United States v. Ponticelli, 622 F.2d 985 (9th Cir. 1980), excludes some statements of state of mind under Federal Rule 803(3) that lack "contemporaneity" with an "event" and that therefore suggest a bad faith motive to fabricate. Rule 803(3) itself contains no such requirement. Importing this bad faith analysis transfers the question of credibility of hearsay from jury to judge and violates the plain meaning of the Rule. See Valori, supra note 122 , at 505-07. 


\section{B. Supreme Court Interpretations of Rule 702 Enlarge Trial Court Discretion}

In cases applying Federal Rule $702^{124}$ to the admission of expert testimony, the Umited States Supreme Court has articulated a multifactored and increasingly discretionary decision-making process. Starting in 1993 with Daubert v. Merrell Dow Pharmaceuticals, Inc., ${ }^{125}$ the Court addressed whether the Federal Rules superseded the strict doctrinal Frye test, which had governed the admissibility of scientific evidence since 1923. Frye held that the "scientific principle or discovery ... from which [the expert's] deduction is made must be sufficiently established to have gained general acceptance in the particular field in which it belongs." 126

The Court held that, although the explicit text of Rule 702 rejected the Frye test, ${ }^{127}$ it did require that "scientific" knowledge be based on valid science and thus have "evidentiary reliability." 28 The majority opinion in Daubert articulated factors that trial courts should use to determine scientific validity, requiring trial courts to consider such difficult and complex questions as whether the principles or applications of the knowledge have been tested; whether the theory or technique has been subjected to peer review; the known or potential rate of error of a technique; and the degree of acceptance of a technique or theory within the scientific community. ${ }^{129}$ The majority emphasized that this inquiry was to be a flexible one, focused on the principles and methodologies that underlie the expert testimony submitted, not on the conclusions generated. ${ }^{130}$

The majority also emphasized the discretionary approach that trial courts could take to their rather daunting task: "We are confident that federal judges possess the capacity to undertake this review. Many factors will bear on the inquiry, and we do not presume to set out a definitive checklist or test." ${ }^{31}$ The concurring and dissenting opinion in Daubert, written by Chief Justice Rehnquist and joined by Justice Stevens, was less confident that federal trial judges were up to the task conferred upon them by the majority:

\footnotetext{
124. Rule 702 provides:

Testimony by Experts. If scientific, technical, or other specialized knowledge will assist the trier of fact to understand the evidence or to determine a fact in issue, a witness qualified as an expert by knowledge, skill, experience, training, or education, may testify thereto in the form of an opinion or otherwise.

FED. R. Evid. 702.

125. 509 U.S. 579 (1993).

126. Frye v. United States, 293 F. 1013, 1014 (D.C. Cir. 1923).

127. 509 U.S. at 588-89.

128. Id. at 590 .

129. Id. at 593-95.

130. Id. at 594-95.

131. Id. at 593. The Court's confidence echoes Thayer's remarks that trial judges were "fit" for the delegation of discretion that he advocated.
} 
I defer to no one in my confidence in federal judges; but I am at a loss to know what is meant when it is said that the scientific status of a theory depends on its "falsifiability," and I suspect some of them will be, too.

I do not doubt that Rule 702 confides to the judge some gatekeeping responsibility .... But I do not think it imposes on them either the obligation or the authority to become amateur scientists im order to perform that role. ${ }^{132}$

This Essay is not the place to try to resolve this debate between the Justices. Much academic and professional attention has been paid to the role into which trial courts have been thrust by Daubert. What is important is that the Supreme Court has proceeded in its most recent decisions both to confirm and to enlarge the role that trial court discretion must play im the admission of expert testimony. In General Electric Co. v. Joiner, ${ }^{133}$ the Court explicitly rejected a more "stringent" standard of review and held that the test of abuse of discretion applied to the trial court's decision to exclude expert testimony even when exclusion resulted in dismissal of the plaintiff's case, emphasizing that appellate court deference is the "hallmark of abuse of discretion review." $" 134$ In Kumho Tire Co., Ltd., v. Carmichael, ${ }^{135}$ the Court extended its interpretation of Rule 702 under Daubert and held that the trial court's "gatekeeping obligation" to determine evidentiary reliability applied to testimony based on all the types of specialized knowledge listed in the Rule-scientific, technical, and other. ${ }^{136}$ Moreover, the Court held that "a trial court may consider one or more of the specific factors that Daubert mentioned when doing so will help determine that testimony's reliability."137 And the Court made it clear that it expects appellate courts to defer to these admission or exclusion decisions, affording trial courts the most broad range of discretion in choosing whether to use the Daubert factors, in developing a process for deciding the admissibility question, and in reaching their conclusions. ${ }^{138}$

132. Id. at 600-01 (Rehnquist, J., concurring in part and dissenting in part).

133. 522 U.S. 136 (1997).

134. Id. at 143 .

135. 526 U.S. 137 (1999).

136. Id. at 141. "[W]here such testimony's factual basis, data, principles, methods, or their application are called sufficiently into question, the trial judge must determine whether the testimony "has a reliable basis in the knowledge and experience of [the relevant] discipline." Id. at 149 (citation omitted).

137. Id. at 141 .

138.

The trial court must have the same kind of latitude in deciding how to test an expert's reliability, and to decide whether or when special briefing or other proceedings are needed to investigate reliability, as it enjoys when it decides whether that expert's relevant testimony is reliable.... Thus, whether Daubert's specific factors are, or are not, reasonable measures of reliability in a particular case is a matter that the law grants the trial judge broad latitude to determine.

Id. at 152-53. 
Taken together, Joiner and Kumho Tire cordon off an area of judicial decision making at the trial court level that is exceedingly complex and difficult, and now appears to be practically immune from appellate review. It is difficult to imagine any choice of, or application of, Daubert factors that would be held to be erroneous. ${ }^{139}$ The effect of these Supreme Court decisions on predictability, consistency, and fairness of outcomes will be discussed in Part VI.

\section{Trial Court Discretion Broadened to Admit Character Evidence to Prove Conduct}

Federal Rules 413,414 , and 415 , recently enacted by Congress, ${ }^{140}$ now permit specific act character evidence to be used to prove conduct. They provide that other acts of sexual assault and child molestation are admissible for any relevant purpose, in both criminal and civil cases in which the defendant is charged with having committed either a sexual assault or an act of molestation, respectively. ${ }^{141}$ Such relevant purposes include drawing an inference about a person's general character trait or propensity in order to prove that the person acted in conformity with the trait or propensity in committing the charged crime or act. In applying these Rules, however, trial courts must also apply Rule 403 in order to protect the due process and equal protection rights of the criminally accused. ${ }^{142}$ This means that Rules 413 through 415 require the trial court to exercise discretion in three steps: first, to determine the probative value of the character-to-conduct inference in the particular case; second, to determine the Rule 403 dangers that would arise if the prior act is admitted; and third, to balance the probative value against these dangers.

139. The concurring opinion of Justices Scalia, O'Connor, and Thomas does describe a possible type of error: "Though ... the Daubert factors are not holy writ, in a particular case the failure to apply one or another of them may be unreasonable, and hence an abuse of discretion." Id. at 159. And appellate courts have suggested that complete failure to consider the Daubert factors can be an abuse of discretion. See, e.g., Black v. Food Lion, Inc., 171 F.3d 308, 312 (5th Cir. 1999).

140. These rules were part of the Violent Crime Control and Law Enforcement Act of 1994, Pub. L. No. 103-322, 108 Stat. 1796 (1994). Their adoption has prompted a serious debate among evidence specialists. See, e.g., Aviva Orenstein, No Bad Men!: A Feminist Analysis of Character Evidence in Rape Trials, 49 Hastings L.J. 663 (1998); Roger C. Park, The Crime Bill of 1994 and the Law of Character Evidence: Congress Was Right About Consent Defense Cases, 22 FordHaM URBAN L.J. 271 (1995).

141. The key provision is as follows:

Rule 413. Evidence of Similar Crimes in Sexual Assault Cases.

(a) In a criminal case in which the defendant is accuscd of an offense of sexual assault, evidence of the defendant's commission of another offense or offenses of sexual assault is admissible, and may be considered for its bearing on any matter to which it is relevant.

FED. R. Ev1D. 413. Rule 414 is identical to Rule 413 except that it applies to offenses of child molestation; Rule 415 governs evidence of similar acts in civil cascs concerning sexual assault or child molestation and states that it is admissible as provided in Rules 413 and 414. See FED. R. Evid. 413415.

142. See, e.g., United States v. Enjady, 134 F.3d 1427 (10th Cir. 1998). 
These Rules thus abolish, at least with regard to these two types of crimes, the existing bright-line rules that prohibit the prosecution's use of a criminal defendant's character to prove conduct. ${ }^{143}$ Some of the supporters of Rules 413 through 415 have argued that there is a special need for introducing evidence of other acts of sexual assault or child molestation due to the difficulties of prosecuting such crimes and to the societal stereotyping of women who are victims of assaults. ${ }^{144}$ There is also discussion of perimitting the use of character-to-conduct evidence more generally. ${ }^{145}$ So far, however, states have not jumped on the federal bandwagon to admit other specific acts to prove character, even in sexual assault or molestation cases. ${ }^{146}$ Evaluating the desirability of permitting trial judges to admit character-to-conduct evidence under the discretionary standard of Rule 403 must include the risks of relymg on the discretion of the trial court, which will be discussed in Part VI below.

Many commentators believe that trial courts are already admitting character-to-conduct evidence against criminal defendants on their own, $\mathrm{m}$ cases quite apart from Rules 413 through 415 . They do so without any explicit change in the evidence rules, by more loosely applying the categorical tests of Federal Rule 404(b) and its state law analogies. Rule 404(b) permits admission of specific acts only if they are relevant to the prosecution's case on some theory other than the character-to-conduct inference. ${ }^{147}$ The Rule itself lists many of the most salient and commonly used noncharacter-relevance theories, such as motive, opportumity, intent, preparation, plan, knowledge, and identity. The task for the trial court is to

143. Federal Rules of Evidence 404 and 405 reflect this basic principle of Anglo-American evidence law and have their counterpart in all state jurisdictions. They permit only very limited use of the character-to-conduct inference in criminal trials, and then only if raised first by the criminal defendant. Specific acts, moreover, may never be used to raise the character inference. See FED. R. Evid. 404, 405.

144. See, e.g., David R. Bryden \& Roger C. Park, “Other Crimes" Evidence in Sex Offenses Cases, 78 MinN. L. Rev. 529 (1994).

145. See generally Roger C. Park, Character at the Crossroads, 49 HAstings L.J. 717, 777 (1998) ("The rules of character evidence are so frustrating that it is teinpting to give up on thein completely, resorting to what I will call 'free balancing'-that is, the Rule 403 approach, perhaps with the scales reversed.").

146. In California, however, the Evidence Code was recently amended to permit the admission of prior acts of domestic violence against others to prove violent conduct charged in the case. CAL. Evid. CODE $§ 1107$ (West 2000).

147. Rule 404(b) applies in both civil and criminal cases, but the vast inajority of case law involves use of the Rule by the prosecution against criminal defendants. The Rule provides:

Other crimes, wrongs, or acts. Evidence of other crimes, wrongs, or acts is not admissible to prove the character of a person in order to show action in conformity therewith. It may, however, be admissible for other purposes, such as proof of notive, opportunity, intent, preparation, plan, knowledge, identity, or absence of mistake or accident, provided that upon request by the accused, the prosection in a criminal case shall provide reasonable notice in advance of trial, or during trial if the court excuses pretrial notice on good cause shown, of the general nature of any such evidence it intends to introduce at trial.

FEn. R. Evid. 404(b). 
determine whether there is such a valid non-character theory of relevance in the context of the specific case.

This task is an example of what has been described earlier in this Essay as one requiring categorical thinking on the part of the trial judge. The protection against improper admission of specific act evidenceimproper, that is, because it generates nothing but the character-to-conduct inference-lies in the judge's close adherence to the Rule 404(b) categories. The judge must scrutinize the non-character theory of relevance, and msist that this theory have independent meaning in the case-independent, that is, from a generalized notion of "propensity" that dissolves into nothing but a character-to-conduct inference. For example, when the relevance theory that a specific act shows "plan" or "intent" is not really warranted under the facts of the case, the specific-act evidence is likely to trigger the use of sheer propensity reasoming by the trier of fact.

Professor Edward Imwinkelried has been one of the nost outspoken critics of judicial dilution of the Rule 404(b) category of "plan," claiming that "plan' ha[s] become a mere euphemism for bad character." misuse of the "plan" theory of relevance arises most frequently when the proffered prior acts are generally similar in content and context to the crime charged:

[T] he prosecution need show only that there are significant similarities between the charged and uncharged acts and that the acts were temporally proximate. The similarities in methodology need not be distinctive enough to single out the accused as the perpetrator of all the crimes. Nor do the courts ... determine whether a common objective inspires all the crimes.... The tendency to apply this version of the plan doctrine is particularly marked in prosecutions for burglary, drug-related misconduct, and sex offenses. ...

[T] he prosecutor is implicitly saying, "The accused did it once recently; therefore, the accused did it again." 149

A study of cases admitting other specific acts to prove intent also illustrates this problem. ${ }^{150}$ The study found the most striking examples in drug cases: "there, evidence of prior drug activity pours in unexamined on the rationale that, as long as the evidence is probative of 'intent,' the

148. Edward J. Imwinkelried, Using a Contextual Construction to Resolve the Dispute over the Meaning of the Term "Plan" in Federal Rule of Evidence 404(b), 43 U. KAN. L. REv. 1005, 1009 (1995) [hereinafter Imwinkelried, Using a Contextual Construction]; see also Edward J. Imwinkelried, The Plan Theory for Admitting Evidence of the Defendant's Uncharged Crimes: A Microcosm of the Flaws in the Uncharged Misconduct Doctrine, 50 Mo. L. REv. 1 (1985).

149. Imwinkelried, Using a Contextual Construction, supra note 148, at 1011-12 (footnotes omitted).

150. See Andrew J. Morris, Federal Rule of Evidence 404(b): The Fictitious Ban on Character Reasoning from Other Crime Evidence, 17 REv. LiTIG. 181 (1998). 
evidence does not involve the forbidden reasoning." 151 The study is replete with exainples of cases in which the criminal defendant's other act can be connected to the crime charged only under generalized propensity reasoning:

[In] United States v. Kills Enemy ... the court admitted evidence of several earlier marijuana sales as probative of whether the defendant, charged with possession of cocaine with intent to distribute, had mens rea as to the cocaine offense. As is common, the court failed to explain how the evidence of marijuana sales could, without employing a propensity inference, increase the probability that the defendant had possessed the cocaine with criminal intent. In fact, as is common in Rule 404(b) cases, the court failed to explain its reasoning at all..$^{152}$

Such loose application of the categorical requirements of Rule 404(b) occurs because judges believe that a criminal defendant's other specific acts are highly probative of that defendant's subsequent conduct, even when these acts do not fit neatly into the categories of Rule 404(b). Although the courts are not explicitly endorsing character-to-conduct reasoning, they are doing so implicitly; they are finding probative value in the character-like inference that the other act generates. As they loosen the strictures of Rule 404(b), they lend support to proposals that greater discretion be lodged with the trial court. ${ }^{133}$

\section{VI}

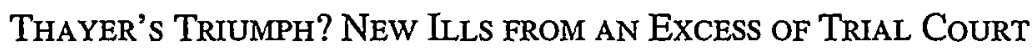 DISCRETION}

There are good reasons to be concerned about an excess of trial court discretion in all three of the areas of evidence law just discussed. This Essay will do no more than suggest some of these reasons, identifying in particular the costs associated with discretion that were described in Part I above. In addition, an excess of trial court discretion also challenges some of the fundamental beliefs that define our system of adjudication. Perhaps these beliefs ought to be challenged, but the challenge should not go unexamined.

First, in the area of hearsay, admitting hearsay through the exercise of trial court discretion is a radical departure from traditional hearsay policy. The drafters of the Federal Rules did consider abandoning the categorical system of exceptions "in favor of individual treatnient in the setting of the particular case... [a]dmissibility would be determined by weighing the probative force of the evidence against possibility of prejudice, waste of

151. Id. at 190.

152. Id. at 191 (footnotes omitted).

153. See, e.g., Park, supra note 145 , at 756-79. 
time, and the availability of more satisfactory evidence."154 Because the probative force of hearsay depends on the evaluation of the declarant's testimonial qualities, it is likely that individual judges' estimates of the trustworthiness (or lack thereof) of individual declarants would vary considerably. The drafters therefore rejected this proposal on grounds similar to those discussed here, namely, the costs of trial court discretion: "minimizing the predictability of rulings, enhancing the difficulties of preparation for trial ...." 155 The drafters were unwilling to rely on the trial judge to make what amounted to credibility decisions, citing the risks of bias and unfairness if such potentially outcome-determinative discretion were reposed in one person. ${ }^{156}$ It has also been argued that a discretionary hearsay rule would create a dynamic of permissive admission, resulting in cases based on hearsay statements about which fewer foundational facts are known, which bear significant sincerity risks, or which are prepared documentary statements. ${ }^{157}$ Movement away from a system premised on receiving testimony from live witnesses and toward a regime of increasing reliance on hearsay raises constitutional issues of due process and confrontation in criminal cases. Even in civil cases, permissive admission would reduce opportunity for cross-examination and benefit the party with the burdens of proof, which is typically the party seeking governmental intervention to change the status quo. Changing the practice of cross-examining witnesses and the traditional allocation of burdens between the parties challenges fundamental beliefs about the fairness of our system of adjudication.

Second, in the area of expert testimony, the degree of appellate deference mandated by the Supreme Court's opinions in Daubert, Joiner, and Kumho Tire will also create problems of excessive trial court discretion. Consistency and predictability in the trial court's method of making decisions about the reliability of expert testimony, and in the outcomes of those decisions, will be lost. Imagine the same expert offering the same type of scientific testimony, based upon the same sources of knowledge, in a series of cases. It will be possible under Kumho Tire for successive trial courts to select different Daubert factors, to apply them differently, and thus to reach different, inconsistent outcomes, admitting or excluding the same expertise. Under the abuse of discretion standard of review, appellate courts will uphold these inconsistent results. ${ }^{158}$ Indeed such inconsistency is

154. FED. R. EvID. 801 advisory committee's note.

155. Id.

156. The advisory committee quoted Professor James Chadbourn in describing such discretion as "altogether atypical, extraordinary." Id. (citation omitted).

157. See Eleanor Swift, Abolishing the Hearsay Rule, 75 CALIF. L. REv. 495, 518-19 (1987).

158. Professor Randolph N. Jonakait contends that when consensus on the reliability of a particlar kind of scientific evidence is lacking, inconsistent trial decisions on the admissibility of expert testimony based on such evidence are not only permissible, they are required under the abuse of 
inevitable under the opinion of the Court in Kumho Tire, which emphasizes that the Court will not refine Daubert into a categorical rule for application in "subsets of cases categorized by category of expert or by kind of evidence." $" 159$

In Joiner, the Court refused to find an abuse of trial court discretion despite the holding of the Court of Appeals below that the trial court had erroneously applied its Daubert analysis to a scientific methodology different from the method actually used by the plaintiffs' experts in their depositions. ${ }^{160}$ If the trial court is not required, through appellate review, to apply Daubert to the expert testimony actually given and the methodology actually used, then its admission or exclusion decisions will be impossible to predict, outcoines will not be consistent, and unfairness will increase, both in appearance and result. In its subsequent opinion in Kumho Tire, the Court adverted, cursorily and unpersuasively, to what it saw as the benefits of unfettered trial court discretion: the need for individualized decision making on the facts of the particular case, ${ }^{161}$ and judicial economy. ${ }^{162}$

discretion standard of review. See Randolph N. Jonakait, The Standard of Appellate Review for Scientific Evidence: Beyond Joiner and Scheffer, 32 U.C. DAvis L. REv. 289, 301-02 (1999) ("Even if such disparate, time-consuming treatment of the same evidence seems unjust or unwise, the appellate courts are powerless to impose a uniform approach.").

159. Kumho Tire, 526 U.S. at 150.

160. See 522 U.S. 136, 151-55 (1997) (Stevens, J., concurring in part and dissenting in part); Joiner v. General Electric Co., 78 F.3d 524, 531-33 (11th Cir. 1996), rev'd, 522 U.S. 136 (1997). According to this argument, the trial court applied its own methodology and examined four epidemiological studies in isolation from each other. It then concluded that none of them could offer reliable support for plaintiffs' experts' conclusions. In so doing, the argument goes, the court ignored the fact that the experts had used a different, "weight of the evidence," methodology that found support in their field. In reversing the district court, the Court of Appeals stated: "Instead of viewing the bases of an expert's opinion as a whole to screen out mere speculation, the district court assessed only a portion of the studies relied upon.... and then excluded the testimony because it drew different conclusions from the research than did each of the experts." Id. at 533. Professor Jonakait finds the Court of Appeals' opinion "persuasive." Jonakait, supra note 158, at 332.

161. See 526 U.S. at 150. In language evocative of the justification for appellate deference to the trial court's application of Federal Rule 403, the Court justified its emphasis on deference: "Too much dcpends upon the particular circumstances of the particular case at issue." Id. One has to wonder, however, what "particularities" of the decision to be made under Daubert and Kumho Tire justify such substantial appellate deference to the trial judge. Appellate courts have access to expert testimony on the same basis as does the trial court, since many decisions about the admissibility of such testimony are made at the summary judgment stage on the basis of the experts' depositions. And even if the expert's testimony is presented for the first time at trial, assessing the scientific validity of the expert's knowledge is not affected by demeanor, by the contextual subtleties of the courtroom, and by the progression of the evidence that do put the trial judge in a better position to apply the Rule 403 balancing test.

162. See 526 U.S. at 152-53. The type of economy referred to, however, seems disingenuous. The Court states that the trial court's discretionary option to admit without inquiry an expert's testimony in "ordinary" cases is cost-saving, and is preserved by the deference afforded by its holding. However, such "ordinary" expertise is already quite likely to be admitted routinely through the use of judicial notice under Federal Rule 201. What Daubert, Joiner, and Kumho Tire do require is relitigation of the question of validity of speculative science, without appellate court guidance. The only savings of judicial resources occurs when plaintiffs' experts are excluded and summary judgments for defendants 
The Court's rigid stance in favor of what seems an excess of trial court discretion to admit or exclude expert testimony challenges the authority of other actors in our adjudication system. It permits trial courts effectively to define the substantive law by controlling the use of essential scientific testimony in certain kinds of substantive cases. For example, one might infer from Daubert and Joiner that, in toxic tort cases at least, trial courts are applying an implicit but unarticulated bright-line requirement that without published epidemiological studies which confirm a causal link between the alleged toxic substance and the plaintiff's medical condition, expert testimony that such a link exists will be excluded. ${ }^{163}$ Without such testimony, plaintiffs' cases will be kept from the jury. Such power to add essential elements to a substantive case might better reside with appellate courts or the legislature.

This practice also challenges the jury's traditional authority to decide disputed questions of fact. Perhaps this challenge is the inevitable result of science entering the courtroom. Professor Mirjan R. Damaska observes that the "scientization of proof" strains our system because the hallmarks of jury trial- "the traditional concept of the trial as a continuous, climactic event," party control over the presentation of proof, and the exaggerated ferocity of the adversarial system-are antithetical to decision making based on the complexities of science. ${ }^{164}$ Moreover, the jury's ability to rely on the ordinary indicia of trustworthiness that it uses for nonscientific proof is questionable. ${ }^{165}$ If it is right that jurors' ability to digest scientific expertise should be in doubt in an increasing number of cases, then ways to resolve the resulting tension between jury trial and the undoubted need for and utility of such expertise should be developed. It is not best resolved by unreviewed trial court discretion to admit or exclude that expertise.

Finally, in the area of character evidence, there are important reasons not to delegate discretionary admission of character-to-conduct evidence to individual trial judges. Avoiding the extreme difficulty and uncertainty of judging the probative value of this evidence has been one of the principal justifications for the bright-line rule of exclusion. Making estimations of the probability that a specific prior act indicates a person's "character," and that "character" indicates commission of the charged crime, is fraught with

are granted. For a thorough critique of the abuse of discretion standard of review required by Joiner and Kumho Tire, see Jonakait, supra note 158, at 304-35.

163. Professor Lucinda M. Finley contends that the Supreme Court's trilogy of Daubert, Joiner, and Kumho Tire permit trial courts to exercise a vigorous gatekeeping function, to "wade into disputed scientific tcrritory," and to create the seriously misguided requirement that experts must base their testimony in toxic tort cases on "epidemiological studies that demonstrate the product in question at least doubles the risk of the disease from which plaintiff suffers." Lucinda M. Finley, Guarding the Gate to the Courthouse: How Trial Judges Are Using Their Evidentiary Screening Role to Remake Tort Causation Rules, 49 DePaul L. Rev. 335, 346-48 (1999).

164. Mirjan R. Damaska, Evidence Law Adrift 145 (1997).

165. See id. at 146. 
uncertainty. Off-hand generalizations such as "people who have once committed an illegal act have a propensity or willingness to commit a similar act again" might support a threshold finding that a prior act is "relevant" to prove conduct, because the standard of probability required for relevance under Rule 401_-"any tendency"-is so low. ${ }^{166}$ For a judge to find probative value beyond relevance, however, requires a more specific generalization about propensity and a much more definite estimate of the probabilities that the generalization is valid. There seems to be no good reason to believe that trial judges have recently become either more competent or less biased in estimating these probabilities. ${ }^{167}$

Concerns about competence are not the only problem with permitting judges to make probability estimates about character. Character inferences about criminal behavior, and even those for which recidivism statistics provide some support, are based on generalizations about the way that groups of people behave over time. Making judgments about a class of people, and the frequency with which the class repeats conduct, has not traditionally justified sending individuals to prison. ${ }^{168}$ Such judgments, if based upon stereotypes of the propensities of people grouped by race or class, may be not only inaccurate but immoral. ${ }^{169} \mathrm{~A}$ basic principle of our criminal law is that persons be judged for their acts, not for their personalities or their membership in discrete, identifiable groups. ${ }^{170}$ Evidence law's ban on character evidence, combined with the presumption of innocence, burdens the prosecution with presenting act-specific proof that a criminal defendant has committed the charged crime. Admission of other acts to prove a defendant's propensities may effectively dilute this burden and thus challenges the moral norms that underlie our system of criminal

166. See FED. R. EVID. 401.

167. Professor Park states a convincing case against the ability of judges to make these estimates. See Park, supra note 145, at 744-45. He does so, however, in order to argue that juries may be superior at this task, and would at least reduce the dangers of judicial venality, oppression, favoritism, political pressure, and corruption. See also Peter Tillers, What Is Wrong with Character Evidence?, 49 HASTINGS L.J. 781, 790 (1998).

168. Professor Miguel A. Méndez notes that recidivism rates show how much more likely the accused is to commit murder, say, than a person selected at random from the general population. But such rates do not tell us "how much more likely it is that the accused will commit murder because he murdered before." Miguel A. Méndez, Character Evidence Reconsidered: "People Do Not Seem to be Predictable Characters," 49 Hastings L.J. 871, 874 (1998).

169. Professor Katharine $K$. Baker asserts that character evidence is harmful because it narrowly "types" people, confirms social stereotypes, and magnifies potential prejudices, particularly against people different from the decision maker. See Katharine K. Baker, A Wigmorian Defense of Feminist Method, 49 Hastings L.J. 861, 862-65 (1998).

170. Professor Tillers asserts that the character rule "owes its existence to a concern for human autonomy" by which he means that law must treat humans as "autonomous and self-governing creatures." Tillers, supra note 167, at 793 n.27, 795. Therefore, unless one's character is autonomously chosen, it is immoral to punish a person on grounds of character. Tillers attempts to show that there is, in fact, no necessary inconsistency between character and autonomy. See id. at 811-12. Yet he is not prepared to advocate abandoning the general character prohibition. See id. at 830-34. 
justice. The harm done to the liberal ideal of judging the act, not the actor, cannot be calculated on a case-by-case basis, or factored into the balancing process of probative value versus prejudice. Bright-line rules excluding character to prove conduct can instantiate and send a message about these moral norms. ${ }^{171}$

\section{CoNCLUSION}

We cannot know whether Thayer would agree with the thesis of this Essay, that we are currently experiencing an excess of trial court discretion in the application of evidence rules. Nor can we predict his reaction to the challenges that excess discretion poses to basic commitments about adjudication were he still writing today, at the end of the twentieth century. The essential reform that Thayer called for one hundred years ago, the abandonment of specific and detailed rules in favor of discretionary standards, has been made. But the context within which the goods and ills of trial court discretion are to be judged has greatly changed since Thayer's day. Not only has society changed, but also the kinds of cases that go to trial and the issues that they raise have changed.

Our society has increasingly fragmented along lines of racial, economic, and, more recently, technological privilege and underprivilege. These highly visible and highly politicized dividing lines raise significant legal issues and have dramatically changed the kinds of cases that are brought to court. Applications of the evidence rules discussed in this Essay often have (or appear to have) outcome-determinative effects on some of these highly-charged cases. For example, the expansion of the discretionary admission of both hearsay and character evidence has been driven by cases involving drug and other gang-related crimes, raising the specter of racial stereotyping and bias. Class actions brought against technologically sophisticated enterprises for environmental hazards and toxic torts depend on the admission of scientific expertise to establish the link between corporate conduct and harm. Thus, unreviewed discretion lodged in the trial courts to admit or exclude outcome-determinative evidence in such cases assumes far greater legal and political significance than Thayer might have imagined. Should trial court discretion continue to expand the power of trial judges by eroding the bright-line categorical rules that have, for the past one hundred years, defined our system of adjudication? This question about the proper uses of evidence, and of adjudication, in a racially and economically, and increasingly technologically, divided society demands our attention.

171. This is a value of bright-line rules excluding character-to-conduct evidence that is not discussed by Professor Park in analyzing the costs and benefits of the current rule of exclusion. See Park, supra note 145 , at $744,751-54$. But he does mention the role of the current character rule as "moral teacher." Id. at 744. 